\title{
Turbulent shear-stresses and velocity distribution in open-channel flows
}

\author{
Contraintes tangentielles turbulentes \\ et distribution des vitesses \\ dans les écoulements à surface libre
}

B. Gaddini (1) and M. Morganti (2)

Introduction

Open-channel turbulent flows often present considerably complex aspects so that ordinary hydraulic formulas such as the pipe resistance law and logarithmic velocity distribution along the normals to the walls are unfortunately not directly applicable.

It was learned that to determine the velocity field and the friction factor in open-channels with sufficient accuracy, it is necessary to evaluate the effects both of the shape of the cross-section and of the non-uniform distribution of the shear-stresses over the wetted perimeter. These factors in fact determine a threedimensional flow in open channels. The flow can be considered to be defined by the superimposition of a primary flow and a secondary flow. The primary flow actually moves the fluid in the longitudinal direction of the channel. The secondary flow can be separated, according to the classification formulated by Prandtl [11], into a secondary flow of the first kind (a result of variations in the cross-section) and a secondary flow of the second kind (showing closed streamlines that can be grouped in several cells). The latter motion is due to a non-homogeneous distribution of the turbulent velocity fluctuations in the boundary. layer.

\section{Introduction}

Les écoulements turbulents à surface libre présentent un aspect extrêmement complexe, de sorte que les formules ordinaires d'hydraulique, telles que la loi de résistance dans les conduits fermés et la distribution logarithmique des vitesses le long des normales aux parois ne sont malheureusement pas directement applicables.

On a appris que, pour déterminer avec une précision suffisante le champ de vitesses et le coefficient de frottement dans les écoulements à surface libre, il était nécessaire d'évaluer les effets à la fois en fonction de la forme de la section transversale et de la distribution non uniforme des contraintes tangentielles sur le périmètre mouillé. Ces facteurs déterminent en fait, dans les canaux ouverts, un écoulement tridimensionnel. Pour définir cet écoulement, on peut le considérer comme la superposition d'un écoulement primaire et d'un écoulement secondaire. L'écoulement primaire assure effectivement la circulation $d u$ fluide dans la direction longitudinale du canal. L'écoulement secondaire peut être décomposé, suivant la classification établie par Prandtl [11], en un écoulement secondaire de première espèce (résultant des variations de la section transversale) et en un écoulement secondaire de seconde espèce (faisant apparaitre des filets fermés qui peuvent se grouper en plusieurs tourbillons).

(1) Prof. of Hydr., Univ. of Rome, Rome, Italy.

(2) Asst. Prof. of Hydr., Univ. of Rome, Rome, Italy.

(1) Professeur d'hydraulique à l'Université de Rome, Italie. (2) Professeur Adjoint d'hydraulique à l'Université de Rome, Italie.

LA HOUILLE BLANCHE/N ${ }^{\circ}$ 4-1982 
Interesting contributions to a more correct and adequate solution of the problems relating to motion in open channels have been made by several theoretical and experimental studies. However, some of the hypotheses formulated and methodologies proposed still seem to be open to experimental testing or further clarifications.

Marchi [9] illustrated an interesting theoretical hypothesis relating to the validity of the logarithmic velocity distribution for turbulent flows in pipes and openchannels of any shape. By verifying this hypothesis with several experimental results he confirmed the influence of the distribution of the wall shear-stresses on the law of velocity distribution.

To determine shear-stresses along the walls in shallow channels Lundgren and Jonsson [7] compared three different methods, underlining the conceptual validity of the method in which the cross-section is divided by means of lines of zero shear assumed as orthogonals to the isovels. They believed, however, that this method was not generally applicable since these division lines can be assumed to be orthogonals to the isovels only if their curvature varies slowly.

Nevertheless, in order to evaluate the friction factor in flood-plain channels, Chin-Lien Yen and Overton [3] adopted precisely this method of subdividing the crosssection by lines of zero shear. They drew these division lines orthogonally to the isovels, starting from the junction between the middle channel and the flood-plain.

Measurements to determine the orientation of the traces of turbulent-stress principal planes in ducts of non-circular cross-section were carried out by Gessner and Jones [5] and by Perkins [10]. The latter believed it reasonable to hypothesize that the direction with respect to which the turbulent shear-stress value in the cross-section appears to be maximum will always remain aligned to the isovels, even in the presence of secondary currents or of distortions in the flow field due to the shape of the contour.

It therefore seems interesting to analyse turbulent shear-stresses in the cross-section of open-channel flows. In the work reported herein, our aim was thus to obtain the lines of zero shear in a rectangular open-channel. The possibility of assuming a logarithmic velocity distribution along these lines was also verified. In fact, Chao-Lin Chiu [1-2] recently proposed a computational technique for the study of irregular three-dimensional flow fields in natural or artificial open channels, assuming a logarithmic velocity distribution on the orthogonals to the isovels.
C'e dernier mouvernnt est dî̀ à une distribution non homogène des fluctuations de vitesse turbulente dans la couche limite. D'intéressantes contributions à une solution plus correcte et plus adéquate des problèmes relatifs au mouvement dans des canaux ouverts ont été apportées par plusieurs études théoriques et expérimentales. Cependant, certaines hypothèses formulees et certaines méthodologies proposées semblent encore ouvertes à la recherche expérimentale pour de plus amples éclaircissements.

Marchi [9] a exposé une intéressante hypothèse théorique relative à la validité de la distribution logarithmique des vitesses en ce qui concerne les écoulements turbulents dans les conduits fermés ou ouverts quelconques. En vérifiant cette hypothèse par plusieurs résultats expérimentaux, il confirma l'influence de la répartition des contraintes tangentielles pariétales sur la loi de répartition des vitesses.

Pour déterminer les contraintes tangentielles le long des parois dans des canaux à faible profondeur, Lundgren et Jonsson [7] ont comparé trois méthodes différentes, en soulignant la validité conceptuelle de celle dans laquelle la section transversale est divisée au moyen de lignes de contrainte nulle supposées normales aux isovels(1). Ils croyaient cependant que cette méthode n'était pas applicable d'une façon générale, car ces lignes de division ne peuvent être considérées comme normales aux isovels que si leur courbure varie lentement.

Néanmoins, pour évaluer le coefficient de frottement dans des plaines d'inondation, Chin Lien Yen et Overton [3] adoptèrent précisément cette méthode de subdiviser la section transversale par des lignes de contrainte nulle. Ils tracèrent ces lignes de division perpendiculairement aux isovels, en partant de la jonction entre le lit mineur et la plaine d'inondation.

Des mesures pour déterminer l'orientation des tracés des principaux plans de containtes turbulentes dans des conduits à section non circulaire furent effectuées par Gessner et Jones [5] et par Perkins [10]. Ce dernier estimait judicieux de supposer que la direction par rapport à laquelle la contrainte tangentielle turbulente dans la section droite apparait maximale est toujours dans la direction des isovels, même en présence de courants secondaires ou de distorsions dans le champ de l'écoulement dues à la forme du contour.

Il semble par suite intéressant d'analyser les contraintes tangentielles turbulentes dans la section droite des écoulements à surface libre. Dans le travail exposé ci-après, notre but était donc d'obtenir les lignes de contrainte nulle dans un canal ouvert à section rectangulaire. La possibilité d'admettre une distribution logarithmique des vitesses le long de ces lignes fut également vérifiée. En fait, Chao Liu Chiu [1-2] a proposé récemment une méthode de calcul pour l'étude des champs irréguliers d'écoulements tridimensionnels dans les canaux ouverts, naturels ou artificiels, méthode dans laquelle il admet une distribution logarithmique des vitesses sur les normales aux isovels. 


\section{Stress tensor and lines of zero shear}

Let us consider a turbulent flow in a uniform rectangular open channel. At a point $P$ let us assume a system of Cartesian coordinates (see Fig. 1a) with the X-axis parallel to the channel and the $z$-axis horizontal. $U, V$ and $W$ are the mean velocity components at $P$, while the corresponding velocity fluctuations are $u, v$ and $w$.

As is well known, the stress at point $P$ - both viscous and turbulent - is a tensorial quantity of the second order. Its components with respect to the defined coordinate system are given by the symmetrical matrix

\section{Tenseurs de contraintes et lignes de contrainte nulle}

Considérons un écoulement turbulent dans un canal ouvert, rectangulaire et uniforme. Supposons en un point $\mathrm{P}$ un système de coordonnées cartésiennes (Cf. Fig. la) dont l'axe des $\mathrm{x}$ est parallele au canal et l'axe des $\mathrm{z}$ horizontal. $\mathrm{U}, \mathrm{V}$, et $\mathrm{W}$ sont les composantes de la vitesse moyenne en $\mathrm{P}$, tandis que $\mathrm{u}$, $\mathrm{v}$, et $\mathrm{w}$ sont les fluctuations de vitesse correspondantes.

Ainsi que chacun sait, la contrainte au point $\mathrm{P}-\grave{a}$ la fois visqueuse et turbulente - est une quantité tensorielle du second ordre. Ses composantes par rapport au systême de coordonnées défini ci-dessus sont données par la matrice symétrique :

$$
\left(\begin{array}{ccc}
\sigma_{x x} & \tau_{x y} & \tau_{x z} \\
\tau_{y x} & \sigma_{y y} & \tau_{y z} \\
\tau_{z x} & \tau_{z y} & \sigma_{z z}
\end{array}\right)
$$

The $\tau_{n x}$ component in the direction of the $x$-axis of the stress acting on the plane normal to a generic $n$-axis, which lies in the cross-section, is evidently a shear-stress. It can be expressed as a function of the stress tensor components and of the direction cosines $(s, t)$ which the $n$-axis makes with the $y$ and $z$-axes respectively since, in this case, the direction cosine is obviously zero with respect to the $x$-axix:

La composante $\tau_{\mathrm{n}}$ suivant l'axe des $\mathrm{x}$ de la contrainte agissant dans un plan perpendiculaire $\grave{a}$ un axe générique n situé dans la section droite est évidemment une contrainte tangentielle. Elle peut être exprimée en fonction des composantes du tenseur de containte et des cosinus directeurs $(\mathrm{s}, \mathrm{t})$ des angles faits par l'axe des $\mathrm{n}$ respectivement avec celui des y et celui des $\mathrm{z}$, puisque dans ce cas le cosinus directeur est évidemment nul par rapport à l'axe des $\mathrm{x}$.

$$
\tau_{n x}=s \tau_{y x}+t \tau_{z x}
$$

It is this stress which gives rise to tractive forces, hence the interest in this stress component.

In the $y, z$ plane it will be possible to define a line of zero shear along which $\tau_{n x}=0$; with the notations of Figure 1b, equation (1) can thus be written:
C'est cette containte qui donne naissance aux forces de traction, d'ou l'intérêt de cette composante de la contrainte.

Dans le plan $\mathrm{y}, \mathrm{z}$, on pourra définir une ligne de contrainte nulle le long de laquelle $\tau_{n x}=0$; avec les notations de la figure $1 \mathrm{~b}$, l'équation (1) peut alors s'écrire :

$$
\tan \varphi_{*}=--\frac{\tau_{y x}}{\tau_{z x}}
$$

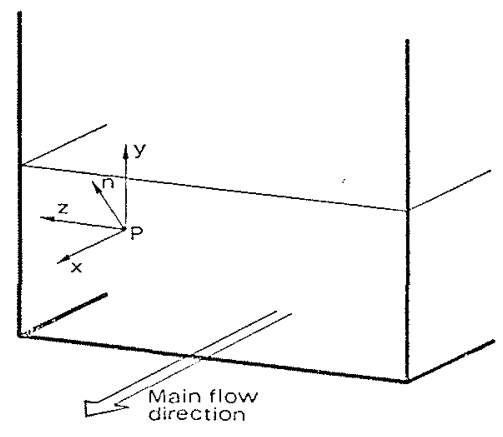

Figure 1a - The coordinate system. Figure la-Système de coordonnées.

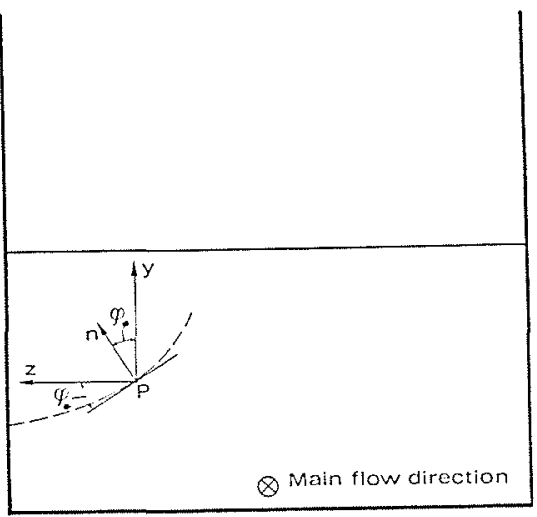

Figure $1 \mathrm{~b}$ - Line of zero shear on the cross-section (dashed line). Figure $1 b$ - Ligne de contrainte nulle sur la section transversale (ligne de tirets).

(1) Isovels = lignes d'égale vitesse. 
It must be noted that the normal direction of the line of zero shear is not a principal direction for the point considered, because in general $\tau_{n m}$, where $m$ is the direction in the $y, z$ plane normal to $n$, will not be zero.

If the conditions of uniformity of motion subsist, these lines remain unvaried along the $x$-axis and form cylindrical surfaces of zero shear with generators parallel to the axis of the flow. In case of non-uniform motion the surface of the lines of zero shear is not cylindrical.

Considering viscous shear-stressess equation (2) becomes $\tan \varphi_{*}=-(\partial U / \partial y) /(\partial U / \partial z)$ : therefore, the lines of zero viscous shear coincide with the lines orthogonal to the isovels of the primary flow.

For turbulent shear-stresses, defined by the product of the fluid density $\rho$ for the second order correlations of the velocity fluctuations, equation (2) becomes:
Il y a lieu de noter que la perpendiculaire à la ligne de containte tangentielle nulle n'est pas une direction principale pour le point considéré, car en général $\tau_{n m}$, où $\mathrm{m}$ est la direction dans le plan $\mathrm{y}, \mathrm{z}$ perpendiculaire à n, n'est pas nul.

Si les conditions d'uniformité de mouvement subsistent, ces lignes restent inchangées le long de l'axe des $\mathrm{x}$ et forment des surfaces cylindriques de contrainte nulle, dont les génératrices sont parallèles à l'axe de l'écoulement. Dans le cas de mouvement non uniforme, la surface des lignes de contrainte nulle n'est pas cylindrique.

Si l'on considère les contraintes tangentielles visqueuses, l'équation (2) devient $\tan \varphi_{*}=-(\partial \mathrm{U} / \partial \mathrm{y}) /$ $(\partial \mathrm{U} / \partial \mathrm{z})$ : en conséquence, les lignes de contrainte tangentielle visqueuse nulle coincident avec les normales aux isovels de l'écoulement primaire.

Pour les contraintes tangentielles turbulentes définies par le produit de la densité $\rho$ du fluide pour les corré. lations de second ordre des fluctuations de la vitesse, l'équation (2) devient :

$$
\tan \varphi_{*}=-\frac{\overline{u v}}{u \bar{w}}
$$

In the case of steady flows, a hot-film anemometer may be employed to measure the value of the two quantities which appear on the right of equation (3), using the technique in which a rotating single sensor is inclined to $45^{\circ}$ with respect to the $x$-axis.

Figure 2 indicates the positioning scheme of the sensor, which lies on the rotating $x, p$ plane. Its tracing on the cross-section is, of course, the $p$-axis. The $r$-axis is normal to $p$. In a generic position, $\varphi$ is the angle formed by the $y$ and $p$ axes, (or by the $z$ and $r$ axes). When the $p$-axis coincides with the $n$-axis, $\varphi$ coincides with the $\varphi_{*}$ angle of equation (3).

If the fluid flowing past the sensor has a velocity with a component normal to the sensor $\left(V_{1}\right)$, and one aligned to it $\left(V_{2}\right)$, the effective cooling velocity $(V)$ of the hot-film is generally expressed [6] by:
Dans le cas d'écoulements permanents, on peut, en adoptant la technique dans laquelle un capteur simple orientable est incliné à $45^{\circ}$ sur l'axe des $\mathrm{x}$, utiliser un anémomètre $a ̀$ film chaud pour mesurer la valeur des deux termes du second membre de l'équation (3).

La figure 2 représente le mode de mise en place du capteur, qui se trouve dans le plan tournant $\mathrm{x}, \mathrm{p}$. Sa trace sur la section transversale est évidemment l'axe p. L'axe r est perpendiculaire à p. Dans une position générique $\varphi$ est l'angle formé par les axes y et $\mathrm{p}$ (ou par les axes $\mathrm{z}$ et $\mathrm{r}$ ). Quand l'axe $\mathrm{p}$ coïncide avec l'axe $\mathrm{n}, \varphi$ coincide avec l'angle $\varphi_{*}$ de l'équation (3).

Si le fluide dans lequel est immergé le capteur a une vitesse dont une composante $\left(\mathrm{V}_{1}\right)$ est perpendiculaire $\dot{a}$ ce capteur et une composante $\left(\mathrm{V}_{2}\right)$ dans le même axe que le capteur, la vitesse effective de refroidissement (V) du film chaud s'exprime généralement [6] par :

$$
V^{2}=V_{1}^{2}+K^{2} V_{2}^{2}
$$

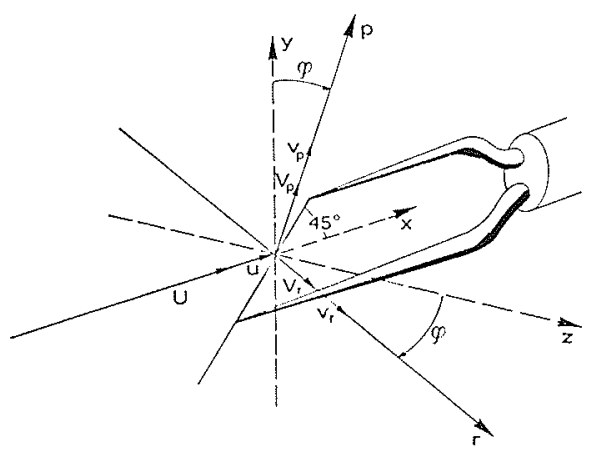

Figure 2 - Definition sketch of the hot-film configuration. Figure 2 - Croquis montrant la disposition du film chaud. 
where $K \ll 1$ and depends almost exclusively on the angle between velocity and sensor. By indicating the components of the instantaneous velocity relative to the $x, p$ and $r$ axes as $U+u, V_{p}+v_{p}, V_{r}+v_{r}$, (i.e. separating the mean velocity from the velocity fluctuation) it follows that: où $\mathrm{K} \ll 1$ et dépend presque exclusivement de l'angle entre la vitesse et le capteur. En désignant par $\mathrm{U}+\mathrm{u}$, $\mathrm{V}_{\mathrm{p}}+\mathrm{v}_{\mathrm{p}}$ et $\mathrm{V}_{\mathrm{r}}+\mathrm{v}_{\mathrm{r}}$ (c'est à dire en séparant la vitesse moyenne de la fluctuation de vitesse) les composantes de la vitesse instantanée relatives aux axes $\mathrm{x}, \mathrm{p}$, et $\mathrm{r}$, il s'ensuit que :

$$
\begin{aligned}
& V_{1}^{2}=\frac{\left(U+u-V_{p}-v_{p}\right)^{2}}{2}+\left(V_{r}+v_{r}\right)^{2}, \\
& V_{2}^{2}=\frac{\left(U+u+V_{p}+v_{p}\right)^{2}}{2} .
\end{aligned}
$$

By substituting these values into equation (4) and developing in series, the effective cooling velocity fluctuations $v$ can easily be expressed by the following equation:
En substituant ces valeurs dans l'équation (4) et en développant en série, les fluctuations effectives de la vitesse de refroidissement $v$ peuvent aisément s'exprimer par l'équation suivante:

$$
v=\frac{1}{\sqrt{2\left(1+k^{2}\right)}}\left[\left(1+K^{2}\right) u-\left(1-K^{2}\right) v_{p}\right]
$$

In order to arrive at equation (5) the hot-film response to turbulent fluctuations was considered linear, according to the generally accepted hypothesis for turbulence intensities lower than 20 or 25 percent. Moreover terms such as $\left(V_{i} / U\right) v_{j}$ (with $i=p, r$ and $j=p$, $r, x)$ can be neglected in series development, since it can be assumed that the secondary velocity components are considerably less than the mean axial velocity.

The velocity $v_{p}$ can be expressed by means of $v$ and w. Rewriting equation (5) for $\varphi=0, \varphi=\pi / 2, \varphi=\pi$ and $\varphi=3 \pi / 2$, respectively, gives four equations : by squaring these, averaging them in time, and then subtracting the first from the third and the second from the fourth, the following relationships can be defined:
Pour arriver à l'équation (5), il a été considéré que la réponse du film chaud aux turbulences était linéaire, suivant lhypothèse généralement admise pour les turbulences inférieures à 20 ou $25 \%$. En outre, les termes tels que $\left(\mathrm{V}_{\mathrm{i}} / \mathrm{U}\right) \mathrm{v}_{\mathrm{j}}$ (avec $\mathrm{i}=\mathrm{p}, \mathrm{r}$ et $\mathrm{j}=\mathrm{p}, \mathrm{r}, \mathrm{x}$ ) peuvent être négligés dans le développement en série, puisqu'on peut admettre que les composantes secondaires de la vitesse sont considérablement plus faibles que la vitesse axiale moyenne.

La vitesse $\mathrm{v}_{\mathrm{p}}$ peut être exprimée au moyen de $\mathrm{v}$ et w. En récrivant l'équation (5) pour $\varphi=0, \varphi=\pi / 2$, $\varphi=\pi$ et $\varphi=3 \pi / 2$ respectivement, on obtient quatre équations : en les élevant au carré, en prenant la moyenne dans le temps, puis en retranchant la première de la troisième et la deuxième de la quatrième, on peut définir les relations suivantes:

$$
\begin{gathered}
\overline{v_{\pi}^{2}}-\overline{v_{0}^{2}}=2\left(1-K^{2}\right) \dot{u v} \\
\bar{v}_{3 \pi / 2}^{2}-\overline{v_{\pi / 2}^{2}}=2\left(1-K^{2}\right) \overline{u w}
\end{gathered}
$$

From equations (6) and (3), the following is obtained:

Des équations (6) et (3) on tire :

$$
\tan \varphi_{*}=\frac{\overline{v_{0}^{2}}-\overline{v_{\pi}^{2}}}{\overline{v_{3 \pi / 2}^{2}}-\overline{v_{\pi / 2}^{2}}}
$$

Equation (7) can be transformed into a relationship among the voltage outputs of the hot-film anemometer when the velocity/voltage calibration curve is known.

Assuming a calibration function such as the one defined in a previous work [4] the velocity/voltage relationship is given by:

L'équation (7) peut, quand on connait la courbe d'étalonnage vitesse/tension, être transformée en une relation entre les tensions de sortie de l'anémomètre à film chaud.

En admettant une fonction d'étalonnage semblable à celle qui a été définie dans un précédent ouvrage [4], la relation entre la vitesse et la tension est donnée par:

$$
v=m \frac{e}{\sqrt{\psi}}
$$

where, $e$ is the instantaneous voltage deviation from the mean, $\psi$ is a function of the probe's electric resistance and $m$ is a term which may be assumed constant at each point for the four positions of $\varphi$ considered. (Further details for the definition of equation (8) are given in the Appendix). où e est la déviation de la tension instantanée par rapport à la moyenne, $\psi$ est une fonction de la résistance électrique de la sonde, et $\mathrm{m}$ est un terme qui peut être admis comme constant en chaque point pour les quatre valeurs de $\varphi$ considérées. (De plus amples détails de la définition de l'équation (8) sont donnés en annexe). 
Introducing equation (8) into equation (7) the following is obtained:
En introduisant l'équation (8) dans l'equation (7) on obtient :

$$
\tan \varphi_{*}=\frac{Z_{0}-Z_{\pi}}{Z_{3 \pi / 2}-Z_{\pi / 2}}
$$

where

$$
\text { oì }
$$

$$
Z_{i}=\frac{\overline{e_{i}^{2}}}{\psi_{i}}(i=0, \pi / 2,3 \pi / 2)
$$

\section{Experimental equipment and procedure}

The experiments were carried out in a steady openchannel flow obtained by means of the recirculating flume shown in Figure 3. From the collecting tank the water is pumped to a constant-head feeding tank. This feeds an inlet-box at a constant flow rate. A system of grids placed at the entrance section reduces large scale disturbances.

The side walls of the flume are made of glass, while the bottom is made of a PVC panel, so that the surfaces are hydraulically smooth. The channel cross-section is rectangular and has dimensions of $29 \times 31 \mathrm{~cm}$. The section in which measurements were taken is $375 \mathrm{~cm}$ downstream from the entrance section and $125 \mathrm{~cm}$ upstream from the end of the channel.

The experimental conditions reported here were realized by regulating the slope of the flume to a value of $0.00106 \mathrm{~m} / \mathrm{m}$ and by suitably adjusting the outflow in order to obtain a constant depth of $10.5 \mathrm{~cm}$.

Due to the limited length of our channel, it was necessary to take special measures in order to promote the development of the flow. The side walls and the bottom of the flume were covered with rough-surfaced rubber strips along an initial $30 \mathrm{~cm}$ tract. In this way an artificial localized roughness was created in order to obtain a more rapid boundary layer development.

\section{Installation et méthodes expérimentales}

Les expériences ont été effectuées dans un écoulement permanent $\dot{a}$ surface libre obtenu au moyen du dispositif de la figure 3. De la cuve de récupération, l'eau est pompée dans le réservoir alimentaire à pression constante. Ce dernier alimente à débit constant un bac intermédiaire, Un système de grilles placé à la section d'entrée atténue les turbulences importantes.

Les parois du canal sont en verre, tandis que le fond est un panneau de $P V C$, de sorte que, du point de vue hydraulique, les surfaces sont lisses. La section droite du canal est rectangulaire, et a $29 \times 31 \mathrm{~cm}$. La section dans laquelle sont effectuées les mesures est à $375 \mathrm{~cm}$ en aval de la section d'entrée et à $125 \mathrm{~cm}$ en amont de l'extrémité du canal.

Les conditions expérimentales décrites ici ont été réalisées en donnant au canal une pente de $0.00106 \mathrm{~m} / \mathrm{m}$ et en réglant le débit de façon à obtenir une profondeur constante de $10,5 \mathrm{~cm}$.

Par suite de la longueur limitée de notre canal, il fallut prendre des mesures particulieres pour faciliter la progression de l'écoulement. Les parois et le fond du canal furent recouvertes sur les 30 premiers centimètres de bandes de caoutchouc à surface nugueuse. De cette façon fut créée une rugosité locale artificielle qui permettait d'obtenir plus rapidement la formation de la couche limite.

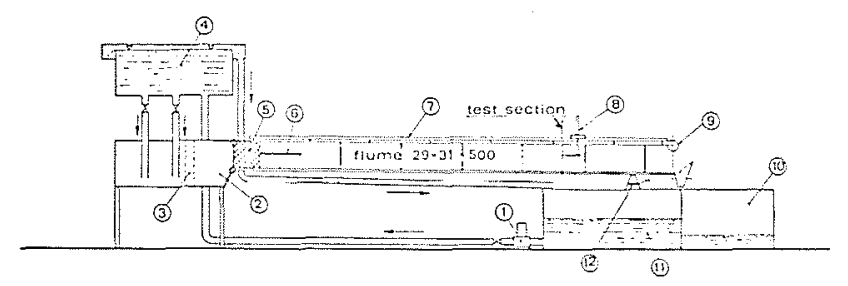

$\begin{array}{ll} & \text { LECEND } \\ 1 \text { - PUNP } & 7 \text { - RAILS FOR CARRIAGE } \\ 2 \text { - INLET BOX } & 8 \text { - INSTRINIENT CARRIAGE } \\ 3 \text { - GRIDS } & 9 \text { - ADJUSTABLE WETR } \\ 4 \text { - CONSTANT HEAD TANK } & 10 \text { - MEASURING TANK } \\ 5 \text { - ARTIFICTAL ROUGHNESS } & 11 \text { - COLLECTING TANK } \\ 6 \text { - DAMPING PLATE } & 12 \text { - JACK }\end{array}$

Figure 3 - The recirculating flume.

Figure 3 - Dispositif expérimental. 
A $50 \times 31 \mathrm{~cm}$ styrofoam damping plate was placed on the free flow surface at the beginning of the flume to attenuate oscillations and thus to allow measurements with the hot-film anemometer at depths as little as $5 \mathrm{~mm}$ below the free surface.

In this work a CTA anemometer system DISA 55 M10 was used. Measurements of the mean velocity and of the r.m.s. of turbulent fluctuations in the axial direction were taken with a conical probe. The sensor had a diameter of $0.6 \mathrm{~mm}$, and was made of quartz-coated nickel. A single cylindrical probe with the sensor at an angle of $45^{\circ}$ to the probe axis was used to determine the direction of the zero turbulent shear-stress planes. The sensor of this inclined probe, $1.25 \mathrm{~mm}$ long and $70 \mu \mathrm{m}$ in diameter, was also made of quartz-coated nickel.

A transverse carriage, mounted on rails, could be moved in the direction of the flow. The holder of the probe was mounted on this carriage so that it could be moved both sideways and in a depthwise direction to the desired measuring position. The inclined probe was mounted on a special support which allowed the axis of the probe to be aligned with the flow axis and the plane of the sensor to be oriented in an $x, y$ or $x, z$ plane or in any other intermediate plane.

In order to determine the trace on the cross-section of the plane where the value of the $\overline{u v}_{n}$ correlation is zero the method described below was followed.

For every measurement point the inclined sensor was placed in four different positions, corresponding to values of $0, \pi / 2, \pi$ and $3 \pi / 2$ of the angle $\varphi$ between the $x, p$ plane and the $x, y$ plane (see Fig. 2).

From the measurements carried out at every point for the different orientations of the sensor, the $\varphi_{*}$ angle which the $x, n$ plane forms with the $x, y$ plane was calculated by means of relationship (9). Two different series of measurements were made to check the steady condition of the flow and to verify if the measurements could be repeated. These checks verified that diepartures from the claculated values of $\varphi_{*}$ were négligible.

In order to convert the voltage output of the hotfilm into velocity measurements, the previously mentioned calibration method was used. This method is based on the definition of a particular calibration curve which proves to be independent of variations in water temperature or probe resistance. It was thus possible to carry out experiments using tap water and without taking special measures to stabilize the flow temperature to a constant value during the experiment. The temperature was measured to $\pm 0.1^{\circ} \mathrm{C}$ accuracy with a mercury thermometer

The mean voltage was measured by means of a DC integrating voltmeter having a 30 sec. time constant. The r.m.s. voltage was evaluated by means of an integrated analogic-digital system. The voltage output of the anemometer was sent to an r.m.s. integrating volt-
Un amortisseur plan de $50 \times 31 \mathrm{~cm}$ en styrofoam(2) fut placé sur la surface de l'écoulement libre, au début du conduit, pour atténuer les oscillations et permettre ainsi des mesures avec l'anémomètre à film chaud jusqu'à des profondeurs de $5 \mathrm{~mm}$ seulement au-dessous de la surface libre.

Dans ces opèrations, un anémomètre CTA système DISA $55 \mathrm{M} 10$ fut utilisé. Les mesures de la vitesse moyenne et de la valeur quadratique des fluctuations turbulentes furent effectuées à l'aide d'une sonde conique. Le capteur avait un diamètre de 0,6 $\mathrm{mm}$, et était en nickel revêtu de quartz. Une sonde cylindrique simple, dont l'axe faisait un angle de $45^{\circ}$ avec le capteur fut utilisée pour déterminer les plans de contraintes tangentielles de turbulence nulle. Le capteur de cette sonde oblique avait $1,25 \mathrm{~mm}$ de long, $70 \mu \mathrm{m}$ de diamètre, et était également en nickel revêtu de quartz.

Un chariot transversal monté sur rails pouvait se déplacer dans la direction de l'écoulement. Le support de la sonde était monté sur ce chariot de façon à pouvoir se déplacer à la fois latéralement et en profondeur pour atteindre la position de mesure voulue. La sonde oblique était montée sur un support spécial qui permettait d'aligner son axe avec celui de l'écoulement, et d'orienter le plan du capteur dans l'un des plans $\mathrm{x}, \mathrm{y}$ ou $\mathrm{x}, \mathrm{z}$, ou dans tout autre plan intermédiaire.

La méthode suivante fut utilisée pour déterminer la trace sur la section transversale du plan où la valeur de la corrélation $\overline{\mathrm{uv}}_{\mathrm{n}}$ est nulle.

En chaque point de mesure, le capteur oblique fut placé dans quatre positions différentes, correspondant aux valeurs $0, \pi / 2, \pi$, et $3 \pi / 2$ de l'angle entre le plan $\mathrm{x}, \mathrm{p}$ et le plan $\mathrm{x}, \mathrm{y}$ (Cf. Fig. 2).

En partant des mesures effectuées en chaque point pour les différentes orientations du capteur, l'angle $\varphi_{*}$ entre le plan $\mathrm{x}, \mathrm{n}$ et le plan $\mathrm{x}, \mathrm{y}$ fut calculé au moyen de la relation (9). Deux séries différentes de mesures furent faites pour contrôler la stabilité de l'écoulement et vérifier que les mesures étaient répétitives. Ces essais confirmèrent que les écarts avec les valeurs calculées de $\varphi_{*}$ étaient négligeables.

Afin de convertir en mesures de vitesses les tensions de sortie du film chaud, la méthode d'étalonnage décrite ci-dessus fut utilisée. Cette méthode est basée sur la définition d'une courbe d'étalonnage particulière, qui s'avère indépendante des variations de température de l'eau et de la résistance de la sonde. On put ainsi faire les expériences en utilisant l'eau du robinet et sans prendre de précautions particulières pour stabiliser la température de l'écoulement à une valeur constante pendant la durée de l'expérience. Cette température fut mesurée avec une précision de $\pm 0,1^{\circ}$ Cà l'aide d'un thermomètre à mercure.

La tension moyenne fut mesurée avec un voltmètre intégrateur à courant continu dont la période d'intégration était de 30 secondes. La tension efficace fut évaluée au moyen d'un système intégré analogique-digital. La tension de sortie de l'anémomètre fut appliquée à un 
meter operating on a $10 \mathrm{sec}$. time constant. The signal was later digitalized by means of an analogic/digital converter at a conversion velocity of 5 readings/ $\mathrm{sec}$ for a period of $180 \mathrm{sec}$. These data were then computed in real time by a digital computer.

\section{Analysis of results}

The characteristics of the flow were observed through the measurement of the mean velocity $U$ in the axial direction of the channel and of the r.m.s. of the velocity fluctuations $\sqrt{u^{2}}$ in the same direction. The isovel patterns on the test section plotted in Figure 4 show how the axial flow is distorted due to the presence of secondary currents. Two maximum values in mean velocity may be observed to the right and to the left respectively of the centre line of the channel. Near the free surface an obvious decrease in velocity may be noticed, so that the value of $(\partial U) /(\partial y)$ is not zero at the free surface.

A similar irregularity in turbulence can be clearly seen in Figure 5, where the lines of constant turbulence intensity $\sqrt{u^{2}} U$ are plotted. The values of $\sqrt{u^{2}} / U$ in the direction of depth are in qualitative agreement with Mc Quivey and Richardson's findings [8]. The measured values show an area of minimum intensity in correspondence to the area maximum mean velocity of the flow and an increase towards the walls. In our case the measurements made near the free surface show a slight increase in the quantity of $\sqrt{u^{2}} / U$, which corresponds to the reduction of $U$ in this area.

The irregularities observed in mean velocity distribution and turbulent fluctuations were due to irregularities in the flume, particularly in the profile of the PVC bottom panel. However, no particular effort was made to eliminate these irregularities since the three-dimensional characteristics of the flow obtained in these conditions made analysis of the experiment even more interesting. voltmètre intégrateur à période d'intégration de 10 secondes. Le signal était ensuite transformé en indication digitale au moyen d'un convertisseur analogique/digital, avec une vitesse de conversion de 5 lectures/seconde pour une période de 180 secondes. Ces données furent ensuite calculées en temps réel par une calculatrice digitale.

\section{Analyse des résultats}

Les caractéristiques de l'écoulement furent observées au moyen des mesures de la vitesse moyenne $\mathrm{U}$ dans l'axe du canal et de la valeur quadratique des fluctuations de vitesse $\sqrt{\mathrm{u}^{2}}$ suivant le même axe. Les réseaux d'isovels sur la section expérimentale de la figure 4 montrent la façon dont l'écoulement axial se déforme par suite de la présence de courants secondaires. Deux valeurs maximales de la vitesse moyenne peuvent être observées à droite et à gauche de l'axe du canal. Près de la surface libre, on peut constater une diminution évidente de la vitesse, de sorte que la valeur de (JU)/ (dy) n'est pas nulle à la surface libre.

On peut voir nettement une irrégularité analogue dans la turbulence sur la figure 5, où sont tracées les lignes d'intensité constante de turbulence $\sqrt{\mathrm{u}^{2}} / \mathrm{U}$. Les valeurs de $\sqrt{\mathrm{u}^{2}} \mathrm{U}$ dans le sens de la profondeur sont qualitativement en accord avec les découvertes de Mc. Quivey et de Richardson [8]. Les valeurs mesurées montrent une zone d'intensité minimale correspondant à la vitesse moyenne locale maximale de l'écoulement, et un acroissement vers les parois. Dans notre cas, les mesures faites près de la surface libre montrent une légère augmentation de $\sqrt{\mathrm{u}^{2} / \mathrm{U}}$, qui correspond à la diminution de $\mathrm{U}$ dans cette zone.

Les irrégularités observées dans la distribution des vitesses moyennes et dans les fluctuations turbulentes étaient dues aux imperfections du canal, et en particulier au profil du panneau de fond en PVC. Cependant, aucun effort particulier n'a été fait pour éliminer ces irrégularités, puisque les caractéristiques tridimensionnelles de l'écoulement obtenues dans ces conditions rendaient encore plus intéressante l'analyse de l'expérience.

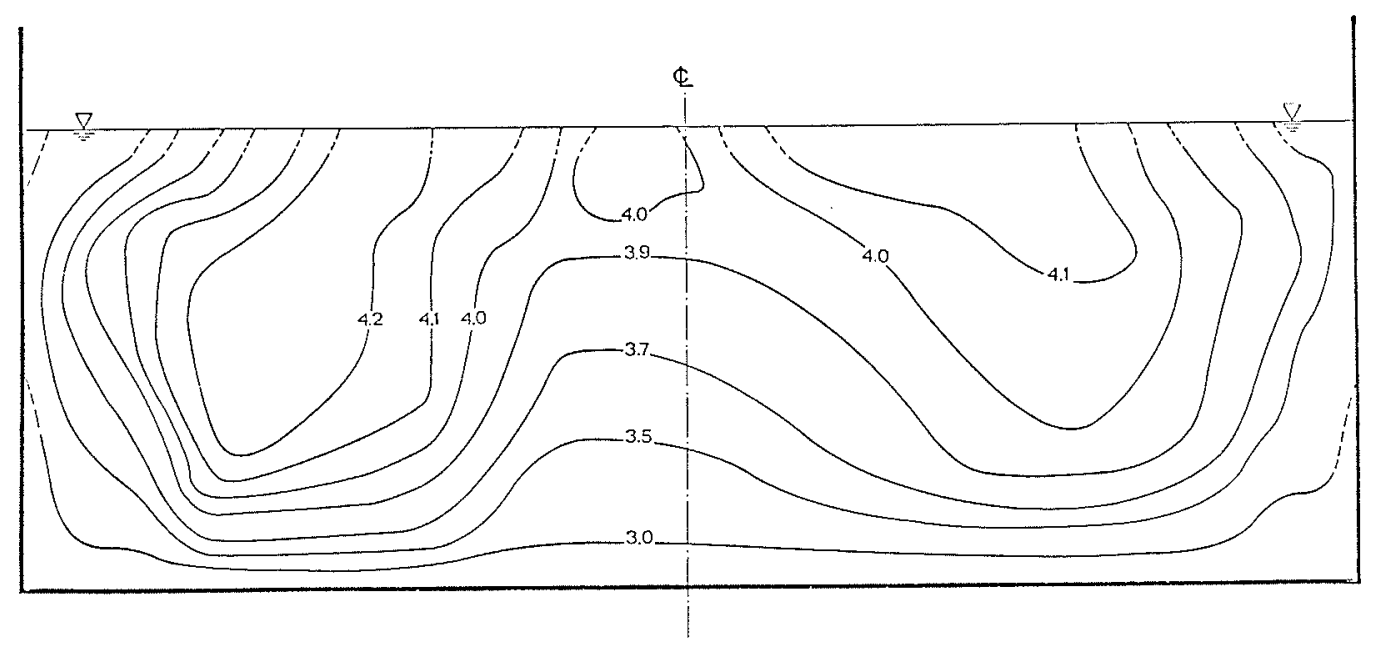

Figure 4 - Isovels of mean veocity $U(\mathrm{dm} / \mathrm{sec})$ on the cross-section.

Figure 4 -I Isovels de la vitesse moyenne $\mathrm{U}(\mathrm{dm} / \mathrm{sec})$ sur la section transversale. 
Figure 6 shows the pattern of the traces on the crosssection of the plane for which the turbulent stress $\overline{\rho u v_{n}}$ is zero. The isovels can also be seen in this figure. In the central zone, where the highest values of the mean velocity are registered, the method of measurement adopted does not provide reliable results due to the low values of the turbulent fluctuations existing in this zone. In fact, if the difference between two r.m.s. signals is of the same order of magnitude as a single r.m.s. signal, the combined measurement errors can be greater than the difference between the two singals.

The results obtained, however, show a convergence of the traces towards the point of maximum flow velocity. Furthermore, by comparing the pattern of these traces to the configuration of the isovels, a quasi perpendicularity between the isovels and the lines for which $\overline{u v_{n}}=0$ may be observed. It thus seems reasonable to conclude that in open-channel flows, even if distorsions of the field of primary velocities are present, the lines traced on the cross-section, which are orthogonals of the isovels, are lines along which both viscous and turbulent shear-stresses in the direction of the flow prove to be zero.

In the analysis of the distribution of velocities on the cross-section of open-channel flows, logarithmic velocity distributions have been adopted either along the lines normal to the bottom, the vertical lines, or the lines perpendicular to the isovels. Due to considerations that we shall discuss later, we feel that a logarithmic velocity distribution seems more justified along the lines of zero shear which, as has been illustrated above,
La figure 6 montre le réseau des traces sur la section transversale du plan pour lequel la contrainte turbulente $\overrightarrow{\rho u v}_{\mathrm{n}}$ est nulle. On peut également voir les isovels sur cette figure. Dans la région centrale, où sont reportées les valeurs les plus élevées de la vitesse moyenne, la méthode de mesure adoptée ne donne pas de résultats valables par suite des faibles valeurs des fluctuations turbulentes existant dans cette région. En fait, si la différence entre deux signaux efficaces est du même ordre de grandeur qu'un seul d'entre eux, les erreurs de mesure cumulées peuvent être supérieures à la différence entre les deux signaux.

Les résultats obtenus montrent cependant une convergence des traces vers le point de vitesse maximale de l'écoulement. De plus, en comparant le réseau de ces traces à la configuration des isovels, on peut observer que les isovels sont à peu près perpendiculaires aux lignes pour lesquelles $\mathrm{uv}_{\mathrm{n}}=0$. Il semble ainsi judicieux de conclure que, dans les écoulements à surface libre, même s'il existe des distorsions du champ des vitesses primaires, les lignes tracées sur la section transversale perpendiculairement aux isovels sont des lignes le long desquelles les contraintes tangentielles, dans le sens de l'écoulement, aussi bien visqueuses que turbulentes, s'avèrent être nulles.

Dans l'analyse de la répartition des vitesses sur la section droite des écoulements à surface libre, on a adopté des répartitions logarithmiques de vitesses, que ce soit sur les lignes perpendiculaires au fond, sur les lignes verticales, ou sur les normales aux isovels. Par suite de considérations que nous discuterons ultérieurement, nous pensons qu'une distribution logarithmique des vitesses semble plus justifiée le long des

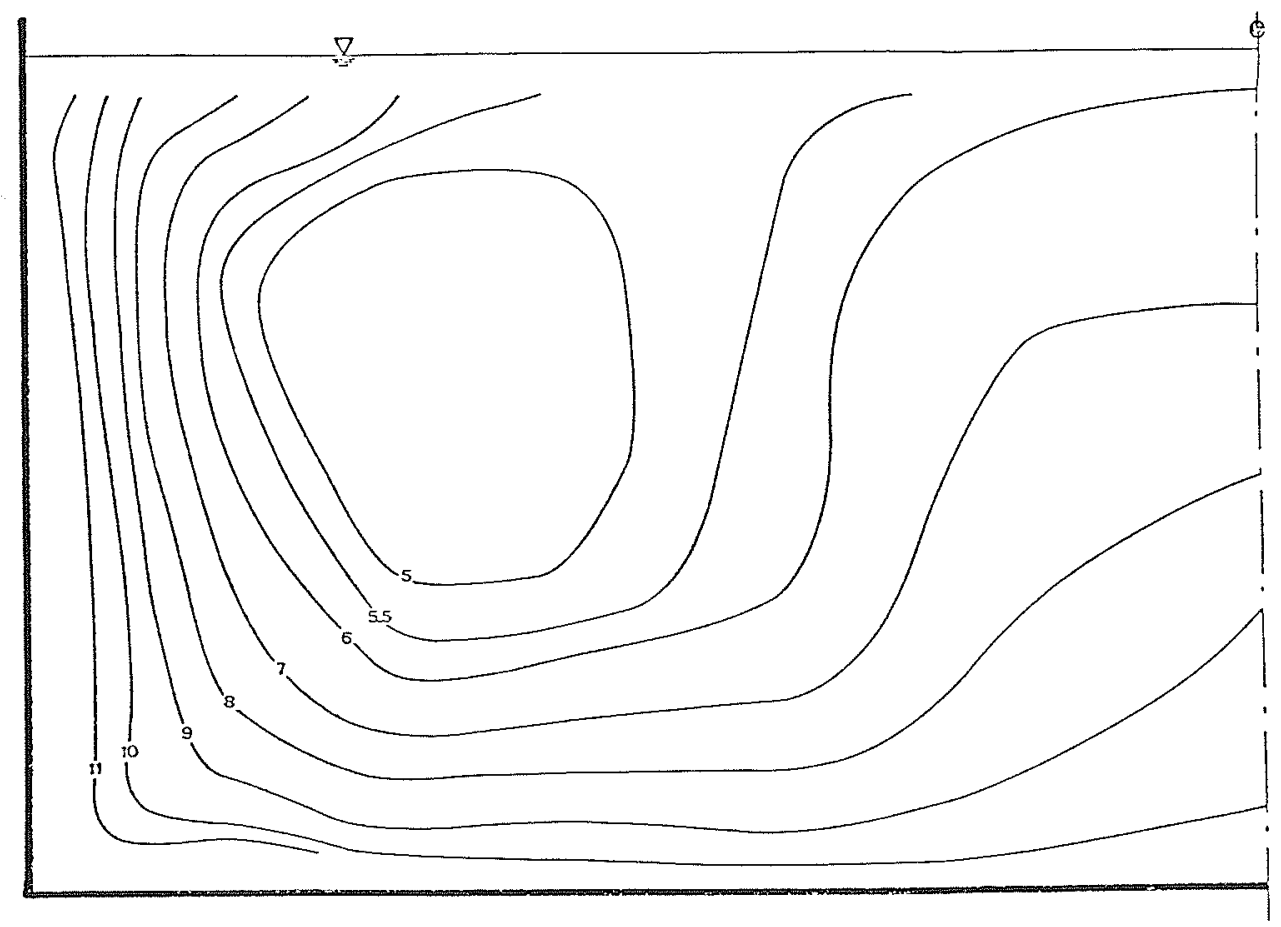

Figure 5 - Lines of constant turbulence intensity $\sqrt{u^{2}} / U$ on the left-half section.

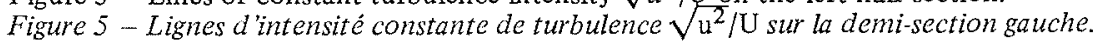




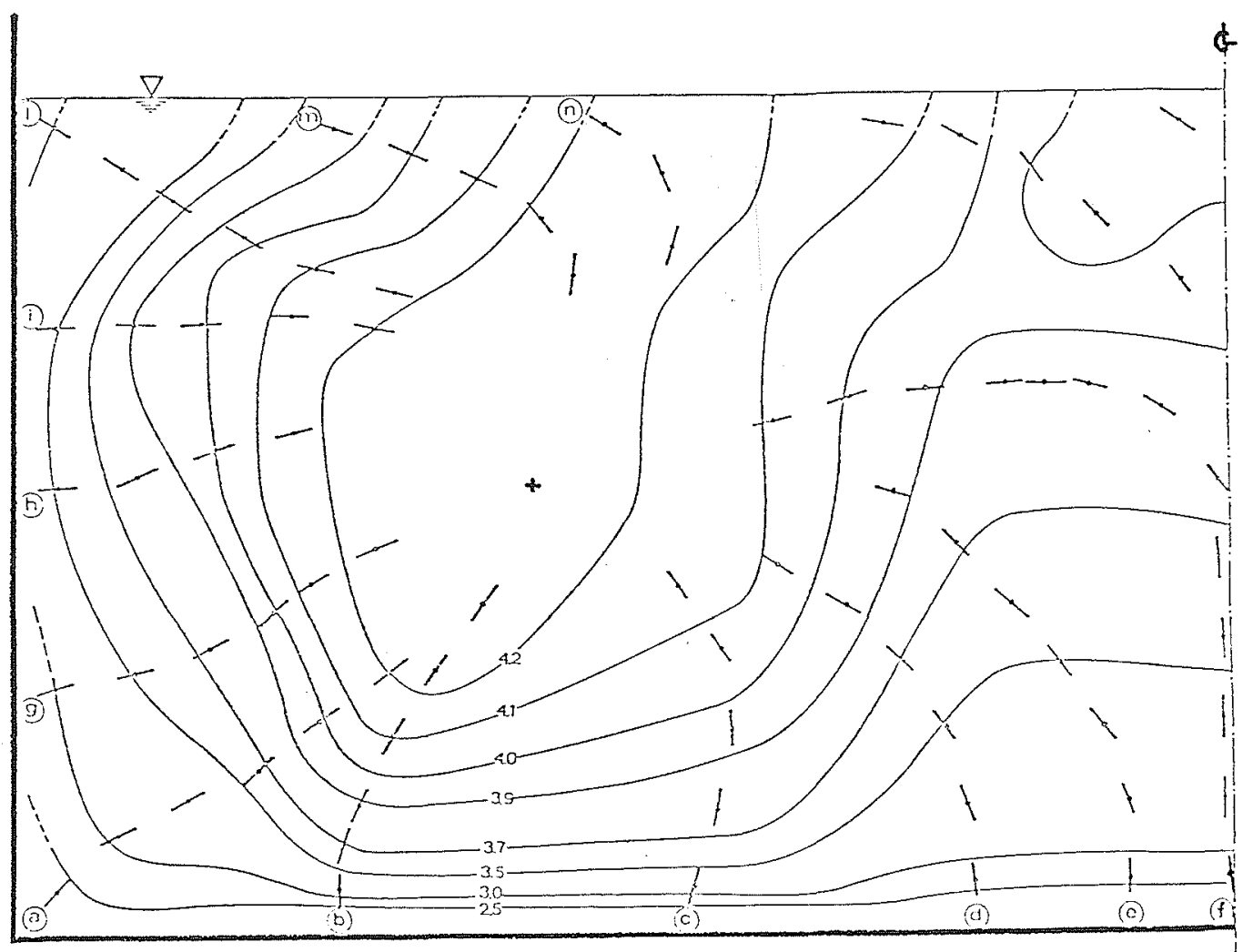

Figure 6 - Lines of zero shear and isovels on the left-half section, (+ point of maximum flow velocity: centre)

Figure 6 - Lignes de contrainte nulle et isovels sur la demi-section gauche (+ point de vitesse maximale de l'écoulement: "centre").

prove to the approximately perpendicular to the isovels, even for a dissymetric distribution of the primary velocity in the section.

This does not question the experimental methods of authors who have used a logarithmic velocity distribution along the lines normal to the walls. In fact, starting from the logarithmic hypothesis along the lines normal to the isovels one arrives at a similar distribution along the lines normal to the bottom, if the isovels can be expressed using a law such as the one proposed by Chao-Lin Chiu [1].

The twelve lines of zero shear obtained in our experiments were thus examined. These can be grouped as follows: six lines beginning at the bottom of the right cross-section, four lines beginning at the right vertical wall, two lines originating at the free surface. As has been mentioned above, Figure 6 shows that the lines of zero shear converge towards a point of maximum primary flow velocity which we shall call centre. This point is about $5.6 \mathrm{~cm}$ from the bottom of the channel and $6.5 \mathrm{~cm}$ from the right wall. At this point the mean velocity was $U_{m}=429 \mathrm{~mm} / \mathrm{sec}$.

Let us now consider the momentum equation for the fluid contained in the control volume shown $\mathrm{j}^{\mathrm{r}}$ Figure 7 , where lines $l$ and $l^{\prime}$ are lines of zero shear which meet at the centre and lines $i$ are isovels. By projecting this equation in the $x$ direction the following is obtained: lignes de contrainte nulle qui, comme il a été exposé ci-dessus, se révèlent approximativement normales aux isovels, même pour une distribution dissymétrique des vitesses primaires dans la section.

Ceci ne remet pas en cause les méthodes expérimentales des auteurs qui ont utilisé une répartition logarithmique des vitesses le long des normales aux parois. En fait, en partant de l'hypothèse logarithrnique le long des lignes normales aux isovels, on arrive à une répartition similaire le long des lignes normales au fond, si les isovels peuvent être exprimées par une loi telle que celle proposée par Chao-Liu Chiu [1].

Les douze lignes de contrainte nulle obtenues dans nos expériences ont donc été examinées. Elles peuvent être groupées comme suit : six lignes commençant au fond de la demi-section transversale droite, quatre à la paroi verticale de droite, deux à la surface libre. Ainsi qu'il a été mentionné ci-dessus, la figure 6 montre que les lignes de contrainte nulle convergent vers un point de vitesse maximale de l'écoulement primaire, que nous appellerons "centre". Ce point est à environ $5,6 \mathrm{~cm}$ du fond du canal et $\grave{a} 6,5 \mathrm{~cm}$ de la paroi de droite. $A$ ce point, la vitesse moyenne était $\mathrm{U}_{\mathrm{m}}=429 \mathrm{~mm} / \mathrm{sec}$.

Considérons maintenant l'équation de quantité de mouvement pour le fluide contenu dans le volume représenté sur la Figure 7, où les lignes 1 et $1^{\prime}$ sont des lignes de contrainte nulle qui se rencontrent au "centre", et les lignes i sont des isovels. En projetant cette équation dans le sens des $\mathrm{x}$, on obtient :

$$
\gamma \propto \mathcal{} S=\iint_{\overline{A B C D}} \tau d a+\iint_{A F E D} \tau d a+\iint \overline{B C E F}_{\bar{A}} \tau d a
$$




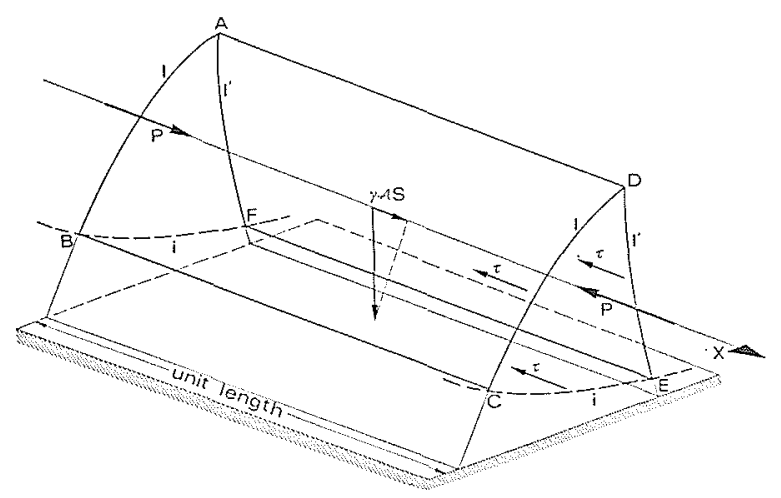

Figure 7 - Equilibrium of forces.

Figure 7 - Equilibre des forces.

where $\mathcal{X}$ is the area of section $\overline{A B F}, S$ is the slope of the water level and $\gamma$ is the specific weight of water. The first two terms on the right side of equation (10) can be neglected since $A B C D$ and $\overline{A F E D}$ are two surfaces of zero shear in the $x$ direction. The third term can be made explicit by calculating the shear-stress according to Prandtl's mixing length theory. In order to determine a velocity distribution law valid in areas of the cross-section which are distant from the walls, it is appropriate to adopt, for the definition of the mixing length $\ell$, Marchi's formula [9] : où $\mathcal{Q}$ est la surface de la section $\overline{\mathrm{ABF}} \mathrm{S}$ la pente $d u$ niveau de l'eau, et $\gamma$ le poids spécifique de l'eau. Les deux premiers termes du second membre de l'équation (10) peuvent être négligés puisque $\overline{\mathrm{ABCD}}$ et $\overline{\mathrm{AFED}}$ sont deux surfaces de contrainte nulle dans le sens des $\mathrm{x}$. Le troisieme terme peut être explicité en calculant la contrainte tangentielle d'après la théorie de Prandtl sur la longueur de mélange. Afin de déterminer une loi de répartition des vitesses valables dans les régions de la section droite éloignées des parois, il convient d'adopter, pour la définition de la longueur de mélange 1, la formule de Marchi [9].

$$
\ell=k \xi e^{-\xi / X}
$$

where $k$ is Karman's constant, $\xi$ is the curvilinear coordinate taken on the middle line of zero shear between $l$ and $l^{\prime}$, originating at the cross-section perimeter, and $X$ is the total length of this line. From equation (10) the following is therefore obtained: où $\mathrm{k}$ est la constante de Karman, $\xi$ la coordonnée curvilinéaire prise sur la ligne médiane de contrainte nulle entre 1 et $1^{\prime}$, prenant son origine sur le périmètre de la section transversale, et $\mathrm{X}$ la longueur totale de cette ligne. De l'équation (10) on tire :

$$
\sqrt{g R S}=k \xi e^{-\xi / X} \frac{d U}{d \xi}
$$

where $R=\widehat{Q} / \widehat{B F}$ is the hydraulic radius of section $\overline{A B F}$. When $\widehat{B F}$ lies on the cross-section perimeter, the relative hydraulic radius is indicated by $R_{0}$, and the corresponding term $\sqrt{g R_{0} S}$ is the local friction velocity $V_{*}$. This leads to the following equation: où $\mathrm{R}=\mathcal{Q} / \widetilde{\mathrm{BF}}$ est le rayon hydraulique de la section $\widehat{\mathrm{ABF}}$. Quand $\overparen{\mathrm{BF}}$ se trouve sur le périmetre de la section transversale, le rayon hydraulique relatif est désigné par $\mathrm{R}_{0}$, et le terme correspondant $\sqrt{\mathrm{gR}_{0} \mathrm{~S}}$ est la vitesse locale de frottement $\mathrm{V}_{*}$. Ceci amène à l'équation suivante:

$$
d U=\frac{V_{*}}{k} \sqrt{\frac{R}{R_{0}}} e^{\xi / X} \frac{d \xi}{\xi}
$$

By supposing that $k$ does not vary along a given line of zero shear, but only from one line to another, and assuming a linear variation of $R / R_{0}$ with respect to $\xi$, the integration of equation (11) is easily obtained. In fact, having set $\ln \eta=\ln (\xi / X)+\phi(\xi / X)$, with
En supposant que $\mathrm{k}$ ne varie pas le long d'une ligne donnée de contrainte nulle, mais seulement d'une ligne à l'autre, et en admettant une variation linéaire de $\mathrm{R} / \mathrm{R}_{0}$ par rapport $\grave{a} \xi$, l'intégration de l'équation (11) peut s'effectuer aisément. En fait, après avoir posé $\ln \eta=\ln (\xi / \mathrm{X})+\phi(\xi / \mathrm{X})$, avec

$$
\phi(\xi / X)=\int_{1}^{\xi / X} \frac{e^{\xi / X} \sqrt{1-{ }^{\xi}}-1}{\frac{\xi}{X}} d\left(\frac{\xi}{X}\right)
$$


the integration of equation (11) leads to the rela- l'intégration de l'équation (11) amène à la relation : tionship:

$$
U=\frac{2.30 V_{*}}{k} \log \left(\eta / \eta_{0}\right)
$$

In order to find $\eta_{0}$ the following condition should be imposed: the function (12) $U=f(\eta)$ must pass through the fixed point (centre) $U=U_{m}$ when $\eta=1$.

In Figures $8,9,10$ the values $(U, \eta)$ obtained on the basis of experimental measurements along the lines of zero shear are shown. These values have been linearly interpolated in order to make the r.m.s. minimum, with the condition of passing through the point $U_{m}=429 \mathrm{~mm} / \mathrm{sec}$ when $\eta=1$, thus obtaining a value of $V_{*} / k$ for each line of zero shear (see Table I).
Il faut, pour trouver $\eta_{0}$, imposer la condition suivante : la fonction (12) $\mathrm{U}=\mathrm{f}(\eta)$ doit passer par le point fixe ("centre") $\mathrm{U}=\mathrm{U}_{\mathrm{m}}$ quand $\eta=1$.

Dans les figures $8,9,10$, sont représentées les valeurs $(\mathrm{U}, \eta)$ obtenues sur la base de mesures expérimentales le long des lignes de contrainte nulle. Ces valeurs ont été interpolées linéairement, afin de rendre minimale la valeur quadratique, avec la condition de passer par le point $\mathrm{U}_{\mathrm{m}}=429 \mathrm{~mm} / \mathrm{sec}$ quand $\eta=1$, ce qui donne ainsi la valeur de $\mathrm{V}_{*} / \mathrm{k}$ pour chaque ligne de contrainte nulle (Cf. Tableau I).

\begin{tabular}{|c|c|c|c|}
\hline \multicolumn{4}{|c|}{$\begin{array}{c}\text { Table I - Values of } V_{*} / k, R_{0} \text { and } k / \sqrt{S} \text { for each the lines of zero shear. } \\
\text { Tableau 1. - Valeurs de } V_{*} / k, R_{0} \text { et } k / \sqrt{S} \text { pour chacune des lignes } \\
\text { de contrainte nulle }\end{array}$} \\
\hline Line & $\begin{array}{c}V_{*} / k \\
(\mathrm{~mm} / \mathrm{sec})\end{array}$ & $\begin{array}{c}R_{0} \\
(\mathrm{~mm})\end{array}$ & $k / \sqrt{S}$ \\
\hline a & 73.9 & 4 & 2.7 \\
\hline$b$ & 39.8 & 34 & 14.5 \\
\hline c & 43.6 & 43 & 14.9 \\
\hline$d$ & 54.3 & 51 & 13.0 \\
\hline e & 51.7 & 88 & 18.0 \\
\hline$f$ & 47.7 & 112 & 22.0 \\
\hline $\mathrm{g}$ & 45.5 & 42 & 14.1 \\
\hline h & 34.9 & 34 & 16.5 \\
\hline$i$ & 28.5 & 28 & 18.4 \\
\hline 1 & 44.1 & 16 & 9.0 \\
\hline $\mathrm{m}$ & 23.8 & 24 & 20.4 \\
\hline $\mathrm{n}$ & 9.7 & 9 & 30.6 \\
\hline
\end{tabular}

For the lines of zero-shear starting at the bottom of the channel, this interpolation leads to limited differences as compared to the experimental values. The relative standard deviation for these lines is on the average 0.025 . Its maximum value is 0.039 (line $b$ ) and its minimum value is 0.013 (line $c$ ). The approximation can thus be considered more than satisfactory. In fact, in our calculations the passage of the inter polated lines through a fixed point $\left(U_{m}\right.$ when $\left.\eta=1\right)$ is imposed, constituting a strongly binding condition, whereas it is usually assumed that $\eta_{0}$ is inversely proportional - with smooth walls - to the friction velocity (the variability of which, is not dealt with in detail).

By means of an analogous interpolation, values of $V_{*} / k$ are obtained for lines of zero-shear starting at the walls. In this case the average relative standard deviation is 0.018 . The maximum deviation is 0.027 (line $g$ ) and the minimum is 0.008 (line $i$ ).

Only two lines of zero-shear starting from the free surface can be reconstructed. For these, the logarithmic interpolation of $U(\eta)$ shows a relative standard deviation of 0.011 .
Pour les lignes de contrainte nulle commençant au fond du canal, cette interpolation mène à des différences limitées par rapport aux valeurs expérimentales. La déviation relative normale pour ces lignes est en moyenne de 0,025. Sa valeur maximale (ligne b) est de 0,039, et son minimum de 0,013 (ligne c). L'approximation peut ainsi être considérée comme plus que satisfaisante. En fait, dans nos calculs, le passage imposé par un point fixe $\left(\mathrm{U}_{\mathrm{m}}\right.$ quand $\left.\eta=1\right)$ des lignes interpolées constitue une condition fortement astreignante, alors qu'il est habituellement admis que $\eta_{0}$ est inversement proportionnel - avec des parois lisses - à la vitesse de frottement (de la variabilité de laquelle on ne tient pas compte en détail).

Au moyen d'une interpolation analogue, on obtient les valeurs de $\mathrm{V}_{*} / \mathrm{k}$ pour les lignes de contrainte nulle commençant aux parois. Dans ce cas, la déviation relative normale moyenne est de 0,018. Le maximum de déviation est de 0,027 (ligne g) et le minimum de 0,008 (ligne i).

On ne peut reconstituer que deux lignes de contrainte nulle partant de la surface libre. Pour ces dernières, l'interpolation logarithmique de $\mathrm{U}(\eta)$ présente une déviation relative normale de 0,011 . 
It seems to us that the only possible way to separate the influence of $V_{*}$ from the influence of $k$ is to estimate the variation of the relative hydraulic radius $R_{0}$. The extrapolation of the lines of zero shear towards the centre of the isovels should not lead to significant errors in the calculation of $R_{0}$. But in order to be able to evaluate the variations of $R_{0}$ along the cross-section perimeter with sufficient continuity, it would be necessary to draw a greater number of lines of zero shear than
Il nous semble que la seule façon possible de séparer l'influence de $\mathrm{V}_{*}$ de celle de $\mathrm{k}$ soit d'estimer la vaviation du rayon hydraulique relatif $R_{0}$. L'extrapolation des lignes de contrainte nulle vers le "centre" des isovels ne doit pas entrainer d'erreur importante dans le calcul de $\mathrm{R}_{0}$. Mais, pour pouvoir évaluer avec une continuité suffisante les variations de $\mathrm{R}_{0}$ le long du périmètre de la section droite, il faudrait tracer un plus grand nombre de lignes de contrainte nulle que
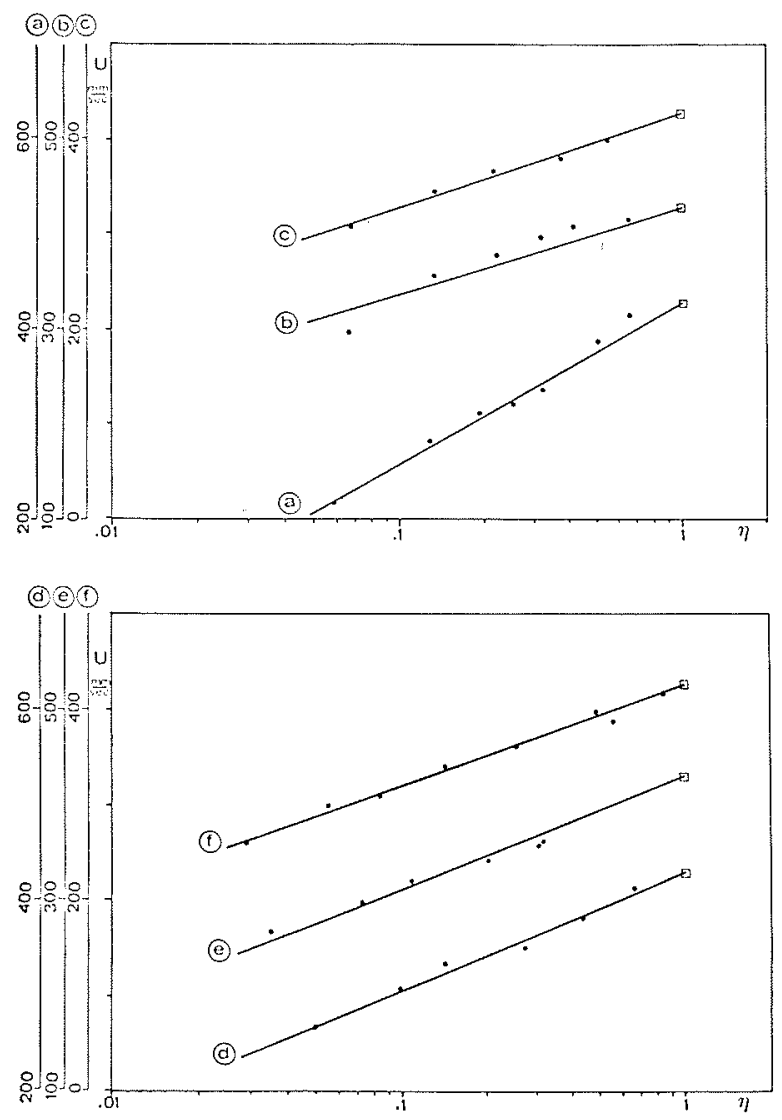

Figure 8 - Mean velocity distribution along the lines of zero shear a-b-c-d-e-f (see Fig. 6).

Figure 8 - Répartition des vitesses moyennes le long des lignes de contrainte nulle $a-b-c-d-e-f$ (Cf. Fig. 6).

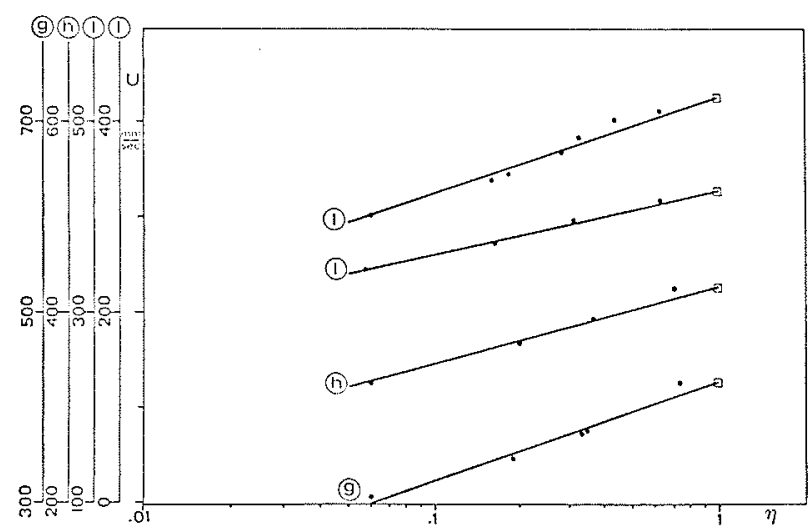

Figure 9 - Mean velocity distribution along the lines of zero shear g-h-i-l (see Fig. 6).

Figure 9 - Répartition des vitesses moyennes le long des lignes de contrainte nulle g-h-i-l-l(Cf: Fig. 6$)$. 


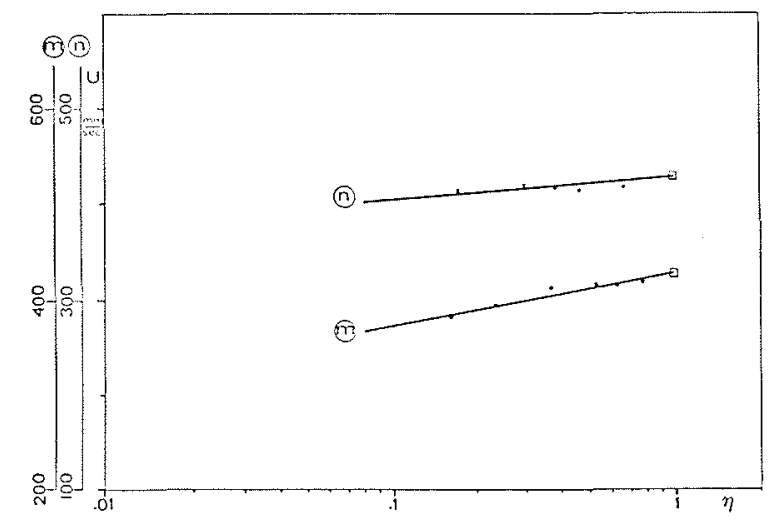

Figure 10 - Mean velocity distribution along the lines of zero shear m-n (see Fig. 6).

Figure 10 - Répartition des vitesses moyennes le long des lignes de contrainte nulle m-n (Cf. Fig. 6).

the twelve obtained in our experiments. Aware of this limitation, we accept - as a first approximation the calculation of $R_{0}$ based on the eleven areas bounded by the above-mentioned twelve lines.

The $R_{0}$ for each of the twelve lines was then calculated by interpolation, obtaining the values shown in Table I. The following relationship could then be established: les douze obtenues dans nos expériences. Conscients de cette limitation, nous acceptons - en première approximation - le calcul de $\mathrm{R}_{0}$ basé sur les onze aires limitées par les douze lignes mentionnées ci-dessus.

Le $\mathrm{R}_{0}$ pour chacune des douze lignes a alors été calculé par interpolation, ce qui a donné les valeurs indiquées au Tableau 1. La relation suivante put alors être établie:

$$
\frac{k}{\sqrt{S}}=\frac{\sqrt{g R_{0}}}{\left(V_{*} / k\right)}
$$

The values of $k / \sqrt{S}$ are indicated in Table 1 and Figure 11. For the lines of zero shear starting at the bottom, but not too close to the corner or the center line, a value of about 14 is obtained for $k / \sqrt{S}(1)$. Near the corner the value of $k$ approaches zero. Towards the center line $k / \sqrt{S}$ increases up to about 1.5 times the above-mentioned value of 14 . On the side wall $k / \sqrt{S}$ has an average value of about 15 ; near
Les valeurs de $\mathrm{k} / \sqrt{\mathrm{S}}$ sont indiquées dans le tableau $I$ et la figure 11. Pour les lignes de contrainte nulle partant du fond, mais pas trop près du coin ni de l'axe, on obtient pour $\mathrm{k} / \sqrt{\mathrm{S}}^{(3)}$ une valeur voisine de 14. Près du coin, la valeur de $\mathrm{k}$ approche de zéro. Vers l'axe, $\mathrm{k} / \sqrt{\mathrm{S}}$ croit jusqu'à près de 1,5 fois la valeur ci-dessus mentionnée de 14. Sur la paroi, $\mathrm{k} / \sqrt{\mathrm{S}}$ a une valeur moyenne voisine de 15 ; vers le coin, elle approche

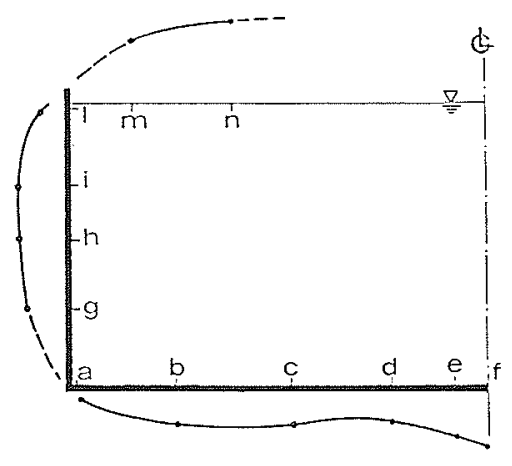

Figure 11 - Distribution of the values of $k / \sqrt{S}$ along the perimeter of the left-half section.

Figure 11 - Répartition des valeurs de $\mathrm{k} / \sqrt{\mathrm{S}}$ le long du périmètre de la demi-section gauche.

(1) Assuming for $S$ the value of the channel slope actually measured by us, the value of $k$ is 0.45 , which is much close to the value generally adopted in turbulent flow in circular pipes.
(3) En prenant pour S la valeur de la pente du canal effectivement mesurée par nous, la valeur ce $\mathrm{k}$ est de 0,45 , ce qui est très voisin de la valeur généralement adoptée pour les écoulements turbulents dans les conduites fermées cylindriques. 
the corner it approaches zero and towards the free surface it decreases rapidilly. On the free surface $k / \sqrt{S}$ is higher, but since only two values are present, we can do no more than observe the increase of $k$ towards the center line of the channel: it seems to fend towards values that are more than double those found on the bottom or the walls.

Since the mixing length is assumed as proportional to $k$ in Prandtl's theory, $k$ must be considered in a certain sense as an increasing function of the degree of freedom with which fluid particles can move as a result of turbulence. Since our flow shows a crosssection which is wider than it is deep, this would explain the greater value of $k$ at the walls as compared to the bottom, as well as the lower values in the corner and the higher values on the free surface.

\section{Conclusions}

On the basis of the experimental results obtained, the following conclusions may be drawn for a threedimensional flow in an open channel of rectangular cross-section:

a) On the cross-section, the lines along which shearstresses prove to be zero in the axial direction of the flow may be taken as orthogonals to the isolvels.

b) Even when considerable distortions of the flow field exist, the mean axial velocity shows a logarithmic distribution along the lines of zero shear.

c) A logarithmic law of mean velocity distribution along the lines of zero shear involves values of Karman's constant which vary along the wetted perimeter in accordance with the boundary conditions on the crosssection. de zéro, et vers la surface libre elle décroit rapidement. Sur la surface libre, $\mathrm{k} / \sqrt{\mathrm{S}}$ est plus élevé, mais puisqu'il n'existe que deux valeurs, nous ne pouvons faire plus que d'observer l'accroissement de $\mathrm{k}$ vers l'axe du canal : il semble tendre vers des valeurs qui sont plus du double de celles trouvées sur le fond ou sur les parois.

Puisque, dans la théorie de Prandtl, la longueur de mélange est considérée comme proportionnelle $\grave{a} \mathrm{k}, \mathrm{k}$ doit, en un certain sens, être considéré comme une fonction croissante du degré de liberté avec lequel les particules fluides peuvent se déplacer du fait de la turbulence. Etant donné que notre écoulement présente une section transversale plus large que profonde, ceci expliquerait la valeur plus grande de $\mathrm{k}$ près des parois par rapport à celle de $\mathrm{k}$ vers le fond, ainsi que les valeurs inférieures dans le coin et supérieures près de la surface libre.

\section{Conclusions}

Sur la base des résultats expérimentaux obtenus, on peut tirer les conclusions suivantes pour un écoulement tridimensionnel dans un canal ouvert à section transversale rectangulaire:

a) dans la section droite, les lignes le long desquelles les contraintes tangentielles s'avèrent nulles suivant la direction axiale de l'écoulement peuvent être considérées comme normales aux isovels.

b) même quand il existe des distorsions considérables du champ de l'écoulement, la vitesse moyenne axiale présente une répartition logarithmique le long des lignes de contrainte nulle.

c) une loi logarithmique de répartition de la vitesse moyenne le long des lignes de contrainte nulle implique des valeurs de la constante de Karman qui varient le long du périmètre mouillé conformément aux conditions limites sur la section transversale.

\section{Annexe I - Appendix I \\ Bibliographie - References}

[1] CHAO-LIN CHIU, HSIUNG D.E. and HSIN-CHI LIM. - Three-dimensional open channel flow, Jour. of the Hydraulics Division ASCE HY8, 1978 .

[2] CHAO-LIN CHIU, HSIUNG D.E. and LIN R.C.H. - Secondary currents under turbulence in open channels, XVIII Congress IAHR, Vol. 3 Subject B, Cagliari, 1979.

[3] CHIN-LIEN YEN and OVERTON D.E. - Shape effects on resistance in flood-plain channels, Jour. of the Hydraulics Division ASCE HYI, 1973.

[4] GADDINI B. and MORGANTI M. - Taratura in acqua del tachimetro a film-caldo in presenza di variazioni della temperatura del fluido e della resistenza della sonda, L'Energia Elettrica, n. 10, 1978.

[5] GESSNER F.B. and JONES J.B. - On some aspects of fully developed turbulent flow in rectangular channels, Jour. of Fluid Mechanics, Vol. 23, part. 4, 1965 .

[6] HINZE J.O. - Turbulence, Mc. Graw Hill, 1975.

[7] LUNDGREN M. and JONSSON I.G. - Shear and velocity distribution in shallow channels, Jour. of the Hydraulics Division ASCE $H Y l, 1964$.

[8] Mc QUIVEY R.S. and RICHARDSON E.V. - Some turbulence measurements in open-channel flow, Jour. of the Hydraulics Division ASCE HYI, 1969.

[9] MARCHI E. - Il moto uniforme delle correnti liquide nei condotti chiusi e aperti, L'Energia Elettrica, n. 4, e 5, 1961.

[10] PERKINS H.J. - The formation of streamwise vorticity in turbulent flow, Jour. of Fluid Mechanics, Vol. 44, part. 4, 1970.

[11] PRANDTL L. - Essentials of Fluid Dynamics, London : Blackie, 1952. 


\begin{tabular}{|c|c|}
\hline & $\begin{array}{l}\text { Appendix II } \\
\text { Notation }\end{array}$ \\
\hline E & : mean voltage \\
\hline$e$ & $\begin{array}{l}\text { : instantaneous values of voltage fluc- } \\
\text { tuations }\end{array}$ \\
\hline$K$ & : a coefficient \\
\hline$k$ & : Kármán's constant \\
\hline$m$ & : a coefficient \\
\hline$R, R_{0}$ & : hydraulic radius \\
\hline & : slope of water level (along direction of $x$ ) \\
\hline$U, V, W$ & $\begin{array}{l}\text { : mean velocities in the } x, y, z \text { direc- } \\
\text { tions, respectively }\end{array}$ \\
\hline$u, v, w$ & $\begin{array}{l}\text { instantaneous values of velocity fluctua- } \\
\text { tions in the } x, y, z \text { directions, respe- } \\
\text { tively }\end{array}$ \\
\hline$U_{m}$ & $\begin{array}{l}\text { maximum axial-velocity in the left. } \\
\text { half section }\end{array}$ \\
\hline$\sqrt{u^{2}} / U$ & : turbulence intensity \\
\hline$V_{*}$ & : friction velocity \\
\hline$v_{n}$ & $\begin{array}{l}\text { : instantaneous values of velocity fluctua- } \\
\text { tions in the } n \text { direction }\end{array}$ \\
\hline$V$ & : effective cooling velocity of the hot-film \\
\hline$v$ & $\begin{array}{l}\text { : instantaneous values of effective cooling } \\
\text { velocity fluctuations }\end{array}$ \\
\hline$x, y, z$ & : directional coordinates \\
\hline$\gamma$ & : specific weight of water \\
\hline$\eta$ & : dimensionless curvilinear coordinate \\
\hline$\xi$ & : curvilinear coordinate \\
\hline$\rho$ & : density of water \\
\hline$\tau$ & : shear-stress in the axial direction \\
\hline$\tau_{n x}, \tau_{y x}, \tau_{z x}$ & $\begin{array}{l}\text { shear-stresses in direction of } x \text { in a plane } \\
\text { at right angles to } n, y \text { and } z \text {, respectively }\end{array}$ \\
\hline $\begin{array}{l}\varphi_{*} \\
\psi\end{array}$ & $\begin{array}{l}: \text { angle formed by the } y \text { and } n \text { axes } \\
\text { : a function of the probe's electric resis- } \\
\text { tance }\end{array}$ \\
\hline
\end{tabular}

Appendix II

Annexe II
Notations

$\mathrm{E}$

: valeurs instantanées des variations de

: coefficient

$\mathrm{k} \quad$ : constante de Karman

$\mathrm{m} \quad$ : coefficient

$\mathrm{R}, \mathrm{R}_{0} \quad$ : rayon hydraulique

$\mathrm{S} \quad$ : pente du plan d'eau (suivant axe des $\mathrm{x}$ )

$\mathrm{U}, \mathrm{V}, \mathrm{W} \quad$ : vitesses moyennes dans les directions

$\mathrm{x}, \mathrm{y}, \mathrm{z}$, respectivement

$\mathrm{u}, \mathrm{v}, \mathrm{w} \quad$ : valeurs instantanées des fluctuations

de vitesses dans les directions $\mathrm{x}, \mathrm{y}, \mathrm{z}$, respectivement

$\mathrm{U}_{\mathrm{m}}$

$\sqrt{\mathrm{u}^{2}} / \mathrm{u}$

$\mathrm{V}$

$\mathrm{V}_{\mathrm{n}}$

$\mathrm{V}$

v

$\mathrm{x}, \mathrm{y}, \mathrm{z}$

$\gamma$

$\eta$

$\xi$

$\rho$

$\tau \quad:$ contrainte tangentielle dans le sens axial

$\tau_{\mathrm{nx}}, \tau_{\mathrm{yx}}, \tau_{\mathrm{zx}}$ : contraintes tangentielles suivant axe des $\mathrm{x}$ dans un plan à angle droit avec $\mathrm{n}, \mathrm{y}$ et $\mathrm{z}$ respectivement

$\varphi_{*} \quad:$ angle formé par les axes y et $\mathrm{n}$

$\psi \quad$ : fonction de la résistance électrique de la sonde.

\section{Appendix III \\ Velocity/voltage relationship}

The velocity/voltage calibration relationship adopted to define equation (8) can be written, as in [4], as follows:

$$
\frac{E^{2}}{\Psi}=Y\left(R_{e}, \theta_{s}\right)
$$

where $E$ is the voltage and $\Psi$ is a function of the electrical resistance $R$ of the probe at $\theta$ (temperature of the fluid), $\theta_{f}$ (temperature of the sensor) and $\theta_{0}=20^{\circ} \mathrm{C}$ (reference temperature). Temperature $\theta_{s}$ is the temperature of the fluid layer adjacent to the où $\mathrm{E}$ est la tension et $\Psi$ une fonction de la résistance électrique $\mathrm{R}$ de la sonde à $\theta$ (température du fluide), $\theta_{\mathrm{f}}$ (température du capteur), et $\theta_{0}$ (température de référence). La température $\theta_{\mathrm{s}}$ est celle de la couche de fluide adjacente au capteur, supposée égale à 
sensor, assumed to be $\theta_{s}=\left(\frac{\theta+\theta_{f}}{2}\right)$ and $R_{e}$ is the Reynolds number relative to the probe, defined by:

$$
R_{e}=\frac{V \delta}{\nu}
$$

where $V$ is the effective cooling velocity, $\delta$ is a dimension of the probe and $\nu$ is the kinematic viscosity of the fluid at temperature $\theta$.

If during measurements a value of the overheat ratio $a=R\left(\theta_{f}\right) / R\left(\theta_{0}\right)$ is adopted so that temperature $\theta_{s}$ is kept constant, equation (13) proves to be a function of $R_{e}$ alone. Equation (13) is valid both for instantaneous velocity and voltage values and for average values. Since the fluctuations of both are small, the velocity/voltage calibration curve may be assumed to be linear over the range of fluctuations.

By differentiating equation (13) and substituting $d V$ with $v$ and $d E$ with $e$ it follows that:

$$
v=2 \frac{\nu}{\delta} \cdot \frac{E}{\Psi} \cdot \frac{d R_{e}}{d Y} \cdot e=\frac{2 v}{\delta} \sqrt{\frac{Y}{\Psi}} \cdot \frac{d R_{e}}{d Y} \cdot e
$$

In the course of our experiments, while measurements were being made at every point for four different positions of the probe $(\varphi=0, \pi / 2, \pi, 3 \pi / 2)$, the water temperature varied only by a few tenths of a degree. Therefore in equation (14) the liquid viscosity may be assumed constant, to an excellent approximation, for the measurements made at every position. It may furthermore be assumed that in the four probe positions $V$ (and with it $R_{e}$ ) varies extremely little: the axial velocity $U$ and coefficient $K$ of equation (4) remain constant, while the components of secondary velocities determine very limited variations of $V$. Consequently $Y$ and $\left(d R_{e}\right) /(d Y)$ may be assumed to be constant in the four positions. Thus, by grouping in $m$ all the constant terms of equation (14), the following relationship is obtained: $\theta_{\mathrm{s}}=\left(\frac{\theta+\theta_{\mathrm{f}}}{2}\right)$, et $\mathrm{R}_{\mathrm{e}}$ est le nombre de Reynolds relatif à la sonde, défini par:

où $V$ est la vitesse de refroidissement effective, $\delta$ une dimension de la sonde, et $v$ la viscosité cinématique du fluide à la température $\theta$.

Si l'on adopte pendant les mesures un taux d'échaufferment $\mathrm{a}=\mathrm{R}\left(\theta_{\mathrm{f}}\right) / \mathrm{R}\left(\theta_{0}\right)$, tel que la température $\theta_{\mathrm{s}}$ reste constante, l'équation (13) devient uniquement fonction de $\mathrm{R}_{\mathrm{e}}$. L'équation (13) est valable à la fois pour les valeurs instantanées de la vitesse et de la tension, et pour les valeurs moyennes. Les variations des deux étant faibles, la courbe d'étalonnage vitesse/tension peut être considérée comme linéaire dans l'étendue des fluctuations.

En différentiant l'équation (13) et en substituant dV par $\mathrm{v}$ et $\mathrm{dE}$ par $\mathrm{e}$, il résulte que :

Au cours de nos expériences, pendant que les mesures tions de la sonde $(\varphi=0, \pi / 2, \pi, 3 \pi / 2)$, la température de l'eau ne varia que de quelques dixièmes de degré. On peut par conséquent avec une excellente approximation considérer, dans l'équation (14), la viscosité du liquide comme constante pour les mesures faites en chaque point. On peut également admettre que, dans les quatre positions de la sonde, $\mathrm{V}$ (et en même temps $\mathrm{R}_{\mathrm{e}}$ ) varie extrêmement peu : la vitesse axiale $\mathrm{U}$ et le coefficient $\mathrm{K}$ de l'équation (4) restent constants, tandis que les composantes des vitesses secondaires déterminent des variations très limitées de V. Par conséquent, Y et $\left(\mathrm{dR}_{\mathrm{e}}\right) /(\mathrm{dY})$ peuvent être considérés comme constants dans les quatre positions. Ainsi, en groupant en $\mathrm{m}$ tous les termes constants de l'équation (14), on obtient la relation suivante : étaient en cours en chaque point pour les quatre posi-

$$
v=m \frac{e}{\sqrt{\Psi}} \text {. }
$$

